V. - ECONOMICS

\title{
Supply of pigs in France \\ (1954-1972)
}

\author{
L. P. MAHÉ \\ Station d'Économie Rurale, E. N.S.A., \\ 65, Route de St-Brieuc, \\ 35042 Rennes Cedex
}

On account of the persistant fluctuations on the pig market and of the statement of our deficit, an attempt was made in this study to define more accurately, on the one hand, the mechanism according to which the producers respond to the prices and, on the other, to compare the evolution of this behaviour with the structural changes of the branch during the period in question. The main results of the analysis were the following :

- sales of pigs during one month depend on the prices of the previous I 8 months ;

- decisions at the beginning of the period may be corrected during the months close to the sales ;

- sales are more sensitive to prices than the production itself;

- contrarily to a wide-spread opinion, structural changes have led to an increased reaction of the farmers to the prices;

- a stabilization cannot be expected only on the basis of modernized structures.

\section{Adjustment of the supply to the demand of pigs and production structures}

\author{
C. BROUSSOLLE
}

Station d'Économie Rurale, E. N.S.A.,

65, Route de Saint-Brieuc, 35042 Rennes Cedex

On account of the aleatory character of the supply and demand of pigs, it is obvious that the importance of the part played by the different categories of production units cannot be estimated only according to the margin obtained by animal or according to the size of these units. Other factors are involved, in particular the contribution of each category to the adjustment of the supply to the demand. In the searching for such a balance, rather small sized units play a counter 
aleatory part of which the overall system takes advantage. Generally speaking, the heterogeneity of the production units provides each system with the flexibility required for obtaining correct reactions to environmental changes.

\title{
VI. - ENVIRONMENT
}

\section{Mineral composition of swine waste. Agronomic value}

\author{
E. SALMON-LEGAGNEUR and R. BERNARD* \\ Station de Recherches sur l'Élevage des Porcs, I. N. R. A., C. N. R. Z., \\ 78350 Jouy en Josas \\ * Union des Coopératives Agricoles d'Alimentation du Bétail, \\ B. P. 85, 02400 Chatean Thierry
}

The aim of the present study was to determine the mincral composition of swine waste. The influence of various factors (storage, physiological stage, ration) was examined. Furthermore a complete study was made on a total of 96 waste samples. The findings show a large variability in the mineral content. The only related parameters seemed to be the total nitrogen content and the ammonia content.

I $\mathrm{m}^{3}$ of swine waste with $5 \mathrm{p}$. Ioo dry matter contains :

- 4.5-II.5 nitrogen units,

- 3-7 potassium units,

- 3.5-7.5 phosphoric acid units.

\section{Influence of a high pesticide (Lindane) level in the diet on ovulation rate and embryonie mortality in the sow}

\author{
P. H. DUEE, G. BORIES*, J. FROC**, M. HASCOET**, \\ Y. HENRY, J. C. PELERAN* and G. CONSEIL
}

Station de Recherches sur l'Elevage des Porcs, I. N. R. A., C. N. R. Z., 78350 Jouy en Josas

* Laboratoire de Recherches sur les Additifs alimentaives, I. N. R. A., Centre de Recherches de Toulouse, 31320 Castanet-Tolosan, B. P. 12

** Laboratoire de Phytopharmacie, I.N.R. A., C. N.R.A., Route de Saint-Cyr,

78000 Versailles

The purpose of the present experiment was to examine if a more or less massive ingestion of the pesticide lindane affects the ovulation rate and embryonic mortality in multiparous sows and to study the distribution of the insecticide within different organs. 